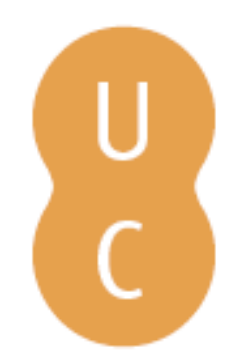

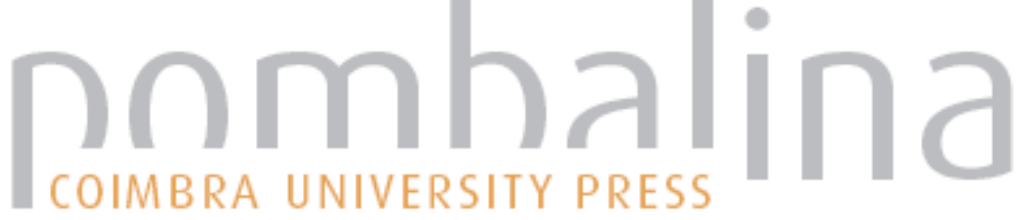

\section{The culture of leisure and tourism: engaging space and sustainability}

\author{
Autor(es): $\quad$ Crouch, David
}

Publicado por: Imprensa da Universidade de Coimbra

URL

persistente: URI:http://hdl.handle.net/10316.2/37362

DOI: $\quad$ DOI:http://dx.doi.org/10.14195/978-989-26-0754-2_1

Accessed : $\quad$ 26-Apr-2023 03:32:23

A navegação consulta e descarregamento dos títulos inseridos nas Bibliotecas Digitais UC Digitalis, UC Pombalina e UC Impactum, pressupõem a aceitação plena e sem reservas dos Termos e Condições de Uso destas Bibliotecas Digitais, disponíveis em https://digitalis.uc.pt/pt-pt/termos.

Conforme exposto nos referidos Termos e Condições de Uso, o descarregamento de títulos de acesso restrito requer uma licença válida de autorização devendo o utilizador aceder ao(s) documento(s) a partir de um endereço de IP da instituição detentora da supramencionada licença.

Ao utilizador é apenas permitido o descarregamento para uso pessoal, pelo que o emprego do(s) título(s) descarregado(s) para outro fim, designadamente comercial, carece de autorização do respetivo autor ou editor da obra.

Na medida em que todas as obras da UC Digitalis se encontram protegidas pelo Código do Direito de Autor e Direitos Conexos e demais legislação aplicável, toda a cópia, parcial ou total, deste documento, nos casos em que é legalmente admitida, deverá conter ou fazer-se acompanhar por este aviso.

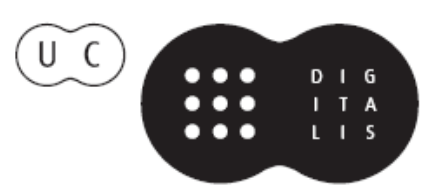


DAVID CROUCH

University of Derby, United Kingdom

\section{THE CULTURE OF LEISURE AND TOURISM :}

ENGAGING SPACEANDSUSTAINABILITY

\section{Introduction}

In this paper I attend to the complexities that surround culture, leisure and tourism. Understanding the ways in which sustainability works requires a deeper articulation of these connections - c-t-l than tend to be available. For one thing, tourism and leisure, or, as I will explain, tourism/leisure, works in a complex relation with culture. To say that requires a clarification of how we might grasp, understand culture as process, complexity and nuance, in the contemporary period. I examine this process through a consideration of how individuals make their own culture, absorbing mediated cultures along the way: our own practice and its meanings in turn fold into and become our future cultural context. As culture is in and of the constitution of meaning, attitudes, values and feelings inform and are informed by these complex and nuanced processes.

In particular I consider the more recent developments of culture from cultural studies in terms of the fluidity between individual and intersubjectivities, and wider, mediated cultural influences, often reduced to contexts. I do this through two particular directions of thought: one, in terms of our performativities in what we do; two, in relation to the matter of space [place, destinations, sites], through a notion of flirting with space. Through these considerations, I set out a means of thinking leisure/tourism relationally, through the notion of play. Thus, how do we, as individuals, find, build a notion of sustainability, how may such be kindled through what we do - ie the "doing" of leisure and tourism? 
In this paper I position tourism and leisure as components of culture, particularly popular culture. Thus, I do not consider "cultural tourism", for example, as a particular category of tourism: tourism, like leisure, can only be cultural. As the cultural theorist Raymond Williams explicated decades ago, "culture is ordinary" (Williams 1977). More recently the critical psychologist John Shotter discussed matters of politics of everyday life and the character of practical ontology, rather than merely "learnt and received" ontology (1993). Into the $20^{\text {th }}$ century, leading cultural theorist Laurie Grossberg has opened the discussions concerning context and lived practice into a more real-life, complex and nuanced, constantly adjusting and changing arena (2000). Each leisure and tourism, are matters of human engagement, mediated and memory-related contexts; of practices, doing, thinking and feeling; of values, attitudes and meaning. It becomes possible to think tourism and leisure in the doing, the making, through what individuals do and feel.

I contest the prevailing idea on tourism business, and much of tourism policy, ie that it itself constructs the tourist's, or the leisure maker's experience. Moreover, rather than merely a matter of a generalised "experience", my attention rests with the ways in which human beings, individuals, more than "tourist" or "leisure maker/doer". Recent developments in cultural studies have shifted the attention of the 1980s and early 1990s emphasis in cultural studies upon contexts, to realise the missing component was always the human being, and her/his active role in matters of being alive, and of doing things, relating to and making sense of them [Crouch 2009). Cultural studies has become engaged in matters of practice, process, and performance-performativity. Mediated contexts emerge as flickering and inflecting, rather than primary or privileged components of process; everyday life, in which I will include doing tourism, is complex and nuanced, as much at least as global networks of governance, corporate action and technology.

The individual does leisure, renders it meaningful in her/his life, similarly does tourism. Each is active, in whatever diverse way and intensity, in constituting their encounter, their doing of things. Indeed, the notion of leisure maker, the most pertinent way to label someone in leisure, pro- 
vokes thought concerning the making, the creative role, of the individual in these processes. My focus surrounds the character of doing each of these cultural practices. Human beings are usually left out of the tourism/ leisure equation; cultural tourism is a no-brainer as all doing of tourism is necessarily a cultural matter.

It thus becomes necessary more adequately and intelligently to reconceptualise "doing tourism and doing leisure", two too easily fragmented components of living. I recompose each of these as merely components of the same thing: how individuals, also inter-subjectively, negotiate their lives, make sense of themselves, others, and the world around them. I point out, too, that the institutions working around tourism and around leisure, and the contractual relationship they have with the individuals, are largely without distinction or differentiation. In short, institutions [business, government etc], do not construct, nor do they largely constitute "what matters" in and how are constituted the doing - practice, feeling, of tourism or leisure, or what doing these things means to people. Furthermore, I argue that there are much greater processes at work. Such an acknowledgement promises to change profoundly how we conceptualise, and argue, claim appropriate institutional responses to what people do. Their negotiation of their lives I consider through the notion of play; play is serious. I work this through a consideration of conceptual insights over more than a decade towards understanding process in terms of performance and an awkwardly-named but very useful notion of performativity; of how things happen and are felt: with possibilities of finding ourselves, being open to change, as well as acknowledging the potential frustration of doing and feeling in living (Crouch 2003, 2005, 2009, 2010; Deleuze and Guattari 2004). Individuals are engaged in negotiating the tensions and potentialities of their lives; how they feel, their identities, relationships, memories and so on: an enormous resources awaiting much fuller and deeper engagement (Grosz 1999).

As a cultural geographer, much of this paper is taken up with articulating anew the ways in which our encounter [doing, thinking, feeling] with space/s affects what happens in doing leisure and tourism, closely thought through a cultural concern (Crouch 2010). Space is no longer to 
be understood as fixed, contained in one meaning; or "home" and "away", habitually identified respectively with leisure and tourism, different activities across our lives, in relation with different sites of action, and across time [including of course memory] are fluid, interactive and commingling. Sites of leisure and/or of tourism [that we may call, for example, "destinations" or "points along the way"] are no exception. Thus I begin with the notion of flirting with space. Along the way in this paper I inflect brief engagement with often core ideas affecting, for example in tourism studies, matters of the importance of the visual, the image, the gaze; and more recently, matters of mobility.

\section{On flirting with space: the journey and its creative potentiality}

In a way, much academic debate has been flirting with space for some time. A post-contextual debate has opened up in cultural studies particularly through Grossberg's interventions that draws space into a relational role in the perpetual figuring and refiguring of culture, identity, power and politics that re-grounds cultural studies out of what he reasons to be a trap of dualities such as state and agency, lives and representations (Grossberg 2000, Wiley 2005). Numerous energies are rendered articulations in a one-dimensional ontology, without hierarchy or deference to particular kinds of context. All energies become multiply engaged in a popular culture and working of social practices of everyday life and their effects. Space, or place, is loosened from a heavy contextualisation in pre-figured culture and put into a more complex dynamic as "an articulation of bodies, materials, discourses and effects; a process that can occur in a wide range of scales and scopes" (Wiley 2005). This generative character of space is set in relation with "the ongoing spatial production of the real" (Grossberg 2000). Agency is the chaos or multiplicity in things and this offers a realignment of subjectivity and power, change and resistance.

In his marvellous story "The Unbearable Lightness of Being", Milan Kundera asks what flirtation is: 
"One might say that it is behaviour leading to another to believe that sexual intimacy is possible, while preventing that possibility becoming a certainty. In other words, flirting is a promise of sexual intercourse without a guarantee" (Kundera 1984:174).

Such pregnancy of possibility, and possibility of becoming; the implicit if possibly agonising playfulness; the very combination of contingent enjoyment, uncertainty, frustration, anxiety and hope would seem to thread across living. Along with these, living holds a felt possibility of connection, meaning, change. To fix may be assurance, certainty or entrapment, closure or a mix of these.

The more explorative, uncertain and tentative ways in which our being part of a world of things, movements, materials and life; openings and closures, part openings mixed with part closures; engaged in living suggests a character of flirting; spaces of possibility. It can be exemplified in the way in which we can come across very familiar sites finding new juxtapositions of materials, materialities and feelings, as it were, "unawares". The unexpected opens out. Ordinary, repetitive, extraordinary, we find that we can "look ... for the first time"; feel the world anew. (Bachelard 1994:156 x). Our emotions become alive in the tactility of our thought; we discover our life and its spaces anew. Time and emotion can deliver the change. However modest these feelings of vitality may be this quiet dynamic can unsettle familiar and expected cultural resonances and the work of politics. What was felt ordinary, mundane and everyday changes; changes in texture and in a feeling of what matters. Encounters like this can happen in diverse, nuanced, complex ways amongst moments of doing things, across different spaces and journeys of our lives and different intensities of encounter. Familiar and habitual rhythmic engagement, meaning and relationships with things can change in register. In these ways flirting is a creative act. My particular concern in this book surrounds cultural and geographical knowledge of fluidities, contingencies and complexities: a practical, embodied ontology of living and the feeling of its doing and becoming (Crouch 2001, Harre 1993, Shotter 1993). 
Flirting is not something in passing, superficial or an alternative to the flaneur. Flirting offers a means through which to explore the character of living spacetime through a number of threads that connect everyday living and our feeling and thinking. It serves as a means to articulate life in its negotiation, adjustment, disorientation and becoming. Whilst it may be caught in more widely dispersed influences and affects of the contemporary, flirting is not offered as a twenty-first century emergence. Flirting with space is a vehicle to explore the dynamics of what is happening and how that flirting can affect things. Yet what is "space" in this context; do we flirt "with" it or is space of the flirting itself, only engaged, not detached or semi-detached from us?

Space may be at once considered a loose entity or mixing of features, movements, energies; ideas, myths, memories, actions; an active ingredient in processes of feeling. Amidst these energies is a rearrangement of energies and the spaces we feel can arise, that we felt we knew but that emerge in new ways different in assemblages of power and meaning. Resembling my approach to everyday knowledge, so too the matter of meaning; incomplete, contingent and temporal. Space can be a vehicle through which the world can emerge and offer stimulation. Space is complex, multiple; existing and constituted in energy, living, doing, thinking and feeling. It is in the commingling of energies; in the feeling and thinking that individuals do that space is affected and affects, affects us, through which richness of life and space emerge. In trying to get closer to the character of flirting with space it seems necessary to engage a compilation of conceptual approaches in order to attend to the multi-faceted character of living and feeling; an active world in which we participate in multiple ways, certain and uncertain, relating memory, relationships, the dynamics between things, actions and ourselves. In the inter-subjective and co-operative acts of individuals a multiplicity of different kinds of life and space occur, offering numerous points of alternative stories, subjectivities and politics. Flirting happens in journeys whether intimate or grand. Its creativities are modest and profound.

Our encounter with space, in making space, or spacing, happens in particular moments as well as through and between flows of spacetime 
and our activity. It does not happen merely though visual responses to particular given sign. Our flirting with space is embodied and multi-sensory (Merleau-Ponty 1969, Crouch 2001, Crouch 2010). Tourism and leisure are no exception (Crouch 2000, 2005). Our feelings of one site/ space relate to our feelings elsewhere, along with our meanings, values and practical ontology.

\section{Brief intermezzo on time, spacetime; belonging and disorientation}

The idea of this flexibility, nuance and complexity, and fluidity of doing and feeling is articulated through aspects of cultural practice [as culture emergent in human lives, inflected by contexts, is borne through more recent conceptualisation through the notion of performance. Rather than a matter of repetition, ritualistic, performance emerges in diverse ways, through performativities. As emergent in the discussion on flirting with space, performance takes varied forms, and frequently contains the "germ" of something new, in ways things are done, how they are felt, and in such "cracks" emerge opportunity for change, adjustment, by accident, unintended (Dewsbury 2000, Grosz 1999, Crouch 2003, Crouch 2011). Unintended feelings and possibility of negotiating like, meanings, attitudes, I new ways and juxtaposition can emerge. This is characterised in going further and bolding on: adventure and feeling differently, and holding onto our identity. Habitually, tourism is regarded as the 'going further', escape, adventure, despite the familiarity so many tourists seek, no matter what opportunity of escape, for example, doing leisure practices in particular sites. Moreover, journeys happen across and through our lives all the time; high intensity and fleeting commingle with the local, habitual and slow.

The idea of "going further and holding on" articulates multiple tensions at work in living. These prompt particular aspects of doing, feeling and thinking through which our worlds are encountered and realised in and across sites, their spaces, practices and times. In this chapter I focus the character and occurrence of these energies through particular themes of 
current theoretical discussion. These open up the character of different kinds of journeys we may make across spacetimes, and moments of creativity that can emerge through flirting with space. In doing so, I hold on to the importance of social, cultural and other contexts, in ways that can be as much background as foreground. The representational character of flows is considered in ongoing, fleeting, fragmenting and re-gathering forms and modalities. Moreover, commingling of affects amongst things we can touch and feel; materiality and non-human life are engaged. I seek to elaborate further the theoretical building across the previous chapters in relation to the diversity of our lives and processes at work.

There is a category of tourism considered to be "heritage tourism". I argue that heritage is characterised in prefigured events, sites or particular kinds of materiality; it is not only "in the past". Heritage is to degree our own; emergent through our actions, desires, memory, they way we do and feel things; how things relate, and we relate with others. Memory is not still; it is mobile, always open to being rediscovered, and revised in relation with other things that happen, familiar spaces being discovered in new ways, unfamiliar sites related with others we know, we knew in different ways and rethought. Heritage is constantly, like Massey writes of space, "in production", contingent (Massey 2005, Crouch 2010a). Insofar as memory emerges, arises, occurs, in individuals creativity, it participates in flirting with space, and spacetime. Our experience, our doing, experience and practical ontology in one space/site relates to other sites in which we perform in a relational way, across space and time.

\section{On play, engaging doing tourism and doing leisure}

Just as earlier I cautioned away from trying to understand, to make sense, of culture in relation with tourism or leisure through traditional institutionally-bias and enframed priorities and criteria, so I present a re-consideration of these significant areas of human activity through diverse but, I argue, crucially related and engaged areas of thought. I recall, too, 
the mid twentieth century philosopher's case that there is nothing as practical as good theory.

"Becoming" is frequently overstated as bearing limitless and effusive energy, a contagion of anxious murmurings; eruption without limit; to be anything (Thrift 2008). Yet amidst much writing on the high-speed, high-powered pace through which significant things happen, there is gradual acknowledgement of the slow, the nuanced:

“... not everything is focused on high-pressured intensity. Embodiment includes tripping falling over, and a whole host of other such mistakes. It includes vulnerability, passivity, suffering and even simple hunger. It includes episodes of insomnia, weariness and exhaustion, a sense of insignificance and even sheer indifference to the whole world. In other words, can and do become overwhelmed' (Thrift 2008:10, my parenthesis). Of course, we can insert more comfortable doings and feelings too. Moreover, intensities are of many different registers, or, one might say, intensities: calm, slowness, unevenness, stillness. 'Play' is serious, with political engagement as it can change attitudes, feelings and relations" (Lee 2000, Crouch 2007, Crouch and Desforges 2003).

Stillness is a "phenomenon, state, pause, symbolic field or geopolitical struggle fizzes, (it) vibrates and resonates... Against the buzz of (an over-technologised) mobility and animation, a typology of stillness haunts the space of flows" (Bissell and Fuller 2009:1 my parenthesis). Anxiety and calm, like speed, distance and being still do not act or flow as a merging duality, but in multiple origins, affects and commingling: tendencies not tropes. There is a fascinating, vibrant if quiet intermixing of different registers and modulations in living: of anxiety and calm, slowness and speed, feeling nearness and far away, or outside the body, "holding on" and "going further"; the timbres of memory.

Something called "Mobility" has been recently very popular in social sciences, often romanticising over long-distance airflight, electronic media and so on (Urry 2007). Mobility is more the energies in living, the very liveliness of our lives, that can make things happen [Deleuze and Guattari 2004]. As Game expresses: 
"A movement is carried out when the body has understood it, that is, when it is incorporated it into its 'world'... it is to allow oneself to respond to their (things) call... motility is not a handmaiden of consciousness" (Game 2001, Merleau-Ponty 62:139).

The philosopher Bakhtin has a visceral take on life, his curiosity with the carnival, the carnivalesque, and Rabelais, an earthiness and fleshiness of living; touch, smell and taste. "Here man (sic) tastes the world, introduces it into his body, makes it part of himself". (Bakhtin 84b:281 my ital). His pinpointing of events in carnival tends to privilege the opportunity of life becoming in terms of particular moments of exceptional openness. It is possible to identify a wider range of situations. I extend his consideration of carnival to diverse examples of play in flirting and becoming: "being lazy", lying in the garden or on the beach, "doing nothing", sitting the day out at the caravan site watching the world go by. Yet, excusing our oppressed guilt, these moments can be profound.

The self-deception or simple romanticisation of much writing concerning 'tourism' is manifest in the over-emphasis of the power of contexts and representations in determining, not even just influencing, what happens. Consideration of process, practice, performance and character of becoming punctures this mirage. Contexts and representations of visual culture and other media are part of the possible materiality and imagination on which individuals draw in affecting the character of encounters yet any more than that shares the romance of the tourism "business" (Crouch and Lubbren 2003, Crouch, Jackson and Thompson 2005).

Richard Powell, an anthropologist of emotions, argues that emotional interaction in what people do in spacetime is an important means through which individuals conduct their lives, and the linkage between negotiating life, belonging and identity. He calls this process play (Powell 2009). Whereas anthropology has tended to understand cultures having particular play that happens around and in relation to ritual practices, in notions of the sacred, Powell draws the notion into more contemporary play as no less significant. Caillois considered play to be where "the ordinary laws of ordinary life are replaced... arbitrary, unexceptional 
rules must be accepted" (Caillois 1961:7). Powell's approach is one that (the spaces that compose such an organisation (of play) are contested and thus involve competing, but always interacting, communities of practice... dissent being performed in and through the spaces of play (Powell 2009:118 my ital). “... the notion of play... acquires a special meaning: it continues a modality which allows the community to connect itself to transcendental agencies, and to establish a sense of community and co-operation between the participants". (Stuckenberger 2005:213, Powell 2009:119).

Such approaches take play seriously, unlike Thrift's approach to play:

"play excludes power, rather than confronts it...as a world of virtual forms, it cannot be connected in the way that is time of work, since it is not made up of fixed means-ends relationships" (Thrift 1997:95).

There is a curious duality in Thrift's claim: work, play. Rather than grasp these respectively as one bundle of experience and another, these are multiply merging and commingling, as on a flat surface, chaotically linked in complex ways, mixed together in life rather than having essentially different isolated character and affect. Play is active and expressive in the tugs of "holding on" and "going further". Play is serious business. Play participates in all aspects of life. In the following paragraphs I engage two aspects of living and its play: doing that is habitually polarised as "leisure" and "tourism", in order to pursue further the relational dynamics of living, space and time and its creativities. Explicitly these considerations avoid dualities and insist upon the repositioning of these suspect dualities in multiply merging flows, not oppositions, as play. They draw forward the examples and arguments progressed in the earlier discussions on belonging and identity.

Caravanners tend to do "holidays" doing caravanning; for the poorer members in particular, their caravan is thirty miles away and their venue for the annual holiday or two. Many allotment holders go abroad for a holiday, others stay in the country for their holiday. Exactly how the temporally mixed flirtings with space they make on from home 
to their site of particular activity, to be with friends, have a holiday, go shopping, there remains is a huge dearth of evidence from which to make interpretation. Yet this serious lack does not seem to stop literatures across the social sciences and humanities; a great cultural and performative drive "between" what are argued distinctive spheres of life: leisure, tourism. There are some emerging efforts to unravel this confusion.

As anthropologist de Botton skilfully narrated autobiographically, we take our lives with us when we go away: relationships, ideas, feelings of belonging and wanting to "get away". (de Botton 2003). Edensor has engaged the mundane character in holidays (Edensor 2006). Most people seem to want to know they will be largely secure when "away" with guided, often detailed information in television programmes (conversation 1990). If our lives are dominated by a search for happiness then perhaps few activities reveal as much about the dynamics of this quest - its ardour and paradoxes - than our journeys of all kinds. The anthropologist Jonathan Skinner discusses the problems with a particular holiday: continuity and discontinuity of relationships, ill health, taking life with us (Skinner 2010). People on holiday talk about things they do "back home".

What we tend to call holidays are frequently, familiarly marked by their everyday not extra-ordinary character. The merging of theme parks (the contemporary "end of the pier" or fairground) and high class hotel and health venues with the kinds of things we may like to get up to "at home": the city fair, in each the feeling and not of wellbeing in doing things and in thinking we are being lazy. The habitual everyday is widespread in being on holiday, where the being is of multiple fragments and moments, from resting, as in the garden, park or armchair, to the beach or hotel poolside; the adventure of white water rafting or dropping into an unexpected club on a Thursday night, with all the possibilities of meeting and uncertainties (Malbon 1999, Cloke and Perkins 1998). In these accounts, observations and narratives there is scarce voice of Baudrillard's fantasy of the super (hyper-) real unreality (Baudrillard 1988). Things they commingle, relate and contrast in multiple ways irrespective of attempts at enforced dualities, rhizomic 
threads across living are adumbrated with negotiations and tensions of holding on and going further.

Complexities of identities and feelings and not of belonging in these playings have numerous multi- and trans-sited character that may include elements of nearby and longer distance trips. To think that "People are tourists most of the time" is surely eccentric (Lash and Urry 1994:259). Non-relationally considered conceptualisations of life slices pursue their category-driven isolations and lacunae. Ironically, what is familiarly called "tourism, we are all tourists now" is submerged in the conflicting ideas of its superficiality (Urry 2003, Ingold 2007a:79-84); significance of experience in as a search for authenticity (MacCannell 1999); escape (Rojek 1993), or a rather ironic, self-conscious playfulness (Urry 2003). In ways it can be all of these, shifting and changing along the way and differently registered by different individuals. But the complexity and diversity is greater than this. As Cohen and Taylor adroitly expressed, escape can be anywhere, anytime (1993). Our being "all tourists now" makes the wrong point: we all have open to us possibilities of being performative and becoming in a multiple holding on and going further anywhere, anytime and anyhow in our living. Another isolation and occlusion of what happens in doing tourism is its peculiar privilege.

Rather than long-distance mobility's gaze changing the sensory register, play has a very embodied and felt character, with potentially severe limits of the imagined "noblest of the senses", a detached visuality. Sally Ness narrates her feeling in visiting Yosemite Falls:

"flowing energy, a moving subject, not a thing. In this context, it seems unremarkable that I had no desire to photograph the Falls during the hike. When I took them in visually, I did so in order to change myself as I was moving. I gazed at them, 'drank' them in, in order to receive energy from the reminder of their presence and the invigorating movement it was continually bringing into my kinesphere... my gazing inspired not an image but the sustainment and continued performance of relatively fatigue-free hiking movements, a kind of phenomenololgical experience that current theories of the tourist gaze, anthropologies of place, and of non-place." (Ness 2007:84) 
To photograph, to take out or lift up the camera would be fixity of the moment's flow and potentialities and of the fluidity of motion and motility of spacing. Indeed, as Game expresses, "being in space is not primarily spectacular, but relates to touch" (Game 1991:167).

The matter and feeling of everyday living is drawn and grooved contingently, part chaotically, across and amongst the diverse felt moments of being alive. Through a consideration of play, its doing and performativity bring the multitude of similar things normatively categorised as a duality (leisure: tourism; work: non-work) into a dynamic multiple relationality. Neither is polarised but fragments related in ways that opens up their character of belonging, disorientations and commonality. Sites, spaces, memory and duration are focused in a revealing of the character of relational space, and the identities, belonging, emotion, a gentle politics at work. Play "can be invitational where it includes others into the sphere... together creating a potential space in which individuals can evoke imaginary powers" (McRobbie 1984). These feelings and energies can be mixtures of positive and negative, as in the case of mixed joys and otherwise of walking the street (Morris 2004). Metcalfe and Game express that "holding space is important because it allows for states of un-integration and formlessness; states of just being where identity can be suspended in creative play, in the absorbed exploration of potential.... Potential space is holding space because it can hold possibilities without seeking to resolve the space through definition" (Metcalfe and Game 2008: 18-19).

In very brief conclusion, the prevailing understanding of culture-tourism-leisure very limited and its re-conceptualisation is overdue. I hope these brief notes have contributed a little to sharing this understanding. 